\title{
Mobile X-Ray Imaging Systems for the Tank Waste Characterization Project at the Hanford Site
}

\author{
J. R. Weber \\ J. K. Keve \\ R. M. Kowitz \\ Westinghouse Hanford Company \\ V. J. Alreja \\ v. J. Technologies \\ Date Published \\ September 1996
}

Prepared for the U.S. Department of Energy Assistant Secretary for Environmental Management

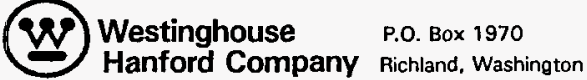

Management end Operations Contractor for the U.S. Department of Energy under Contract DE-AC06-87RL 10930

Copyright Licennes 8 acceptance of this article, the publisher and/or recipient ecknowledges the

L.S. Government's right to retein a nonexclusive, royalty-fres license in and to any copyright covering thie paper.

Approved for public release; distribution is unlimited 
LECAL DISCLAIMER

- This report was prepared as an account of work sponsored by an agency of the United States Government. Neither the United States Government nor any agency thereof, nor any of their employees, nor any of their contractors, subcontractors or their employees, makes any warranty, express or implied, or essumes any legal liability or responsibility for the

accuracy, completeness, or any third party's use or the results of such use of any information, apparatus, product, or process disclosed, or represents that its use would not infringe privately owned rights. Reference herein to any specific commercial product, process, or service by trade name, thademark, manufacturer, or otherwise, does not necessarily constitute or imply its endorsement, recommendation, or favoring by the United States Government of any agency thereof or its contractors or subcontractors. The views and cipinions of authors expressed herein do not necessarily state cr reflect those of the United States Government or any eigency thereof.

This report has been reproduced from the best available copy.

Printed in the Unitad Stutes of Americe

DISCLM-2.CHP (1-91) 


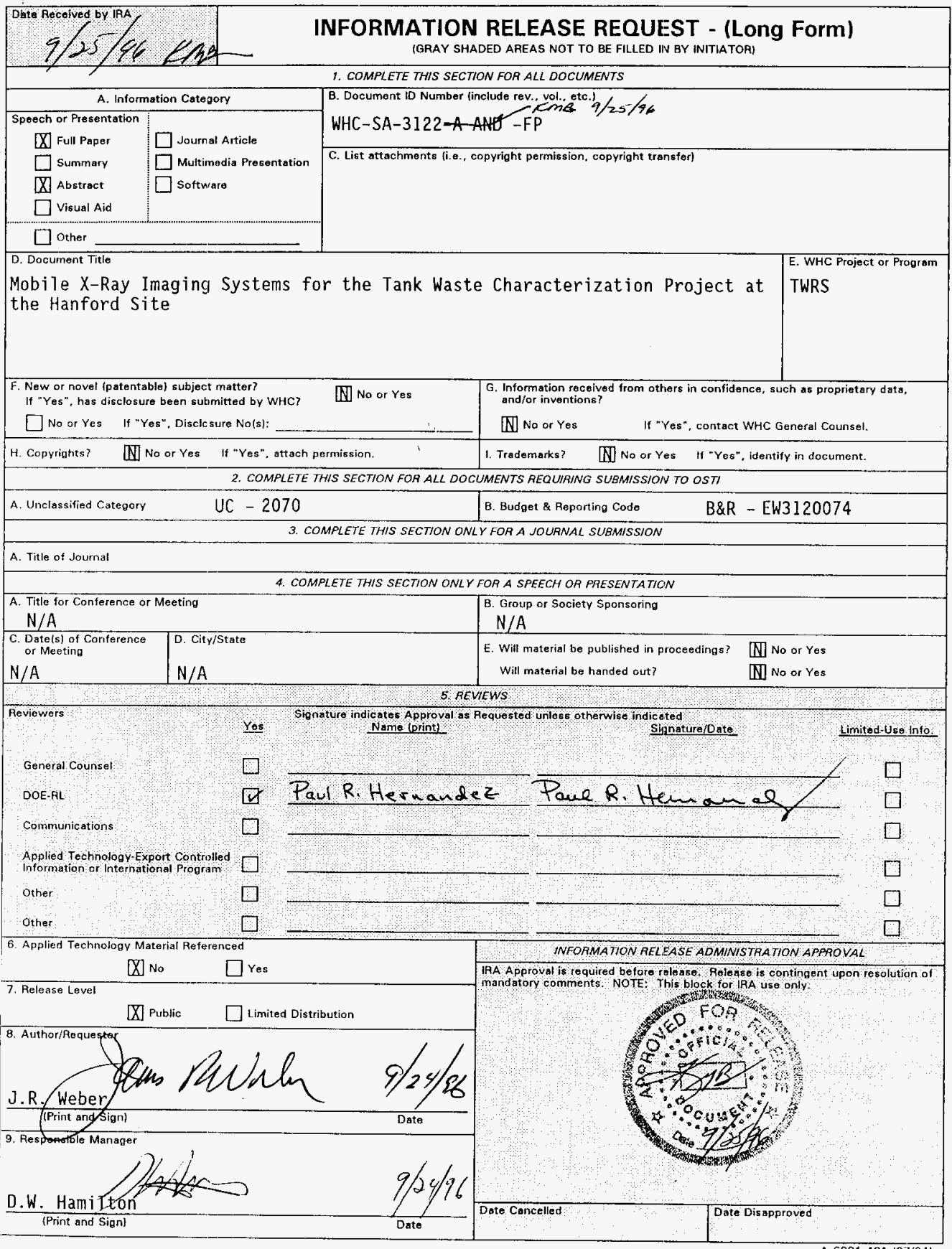


WHC-SA-3122-A-FP

Document ID Number

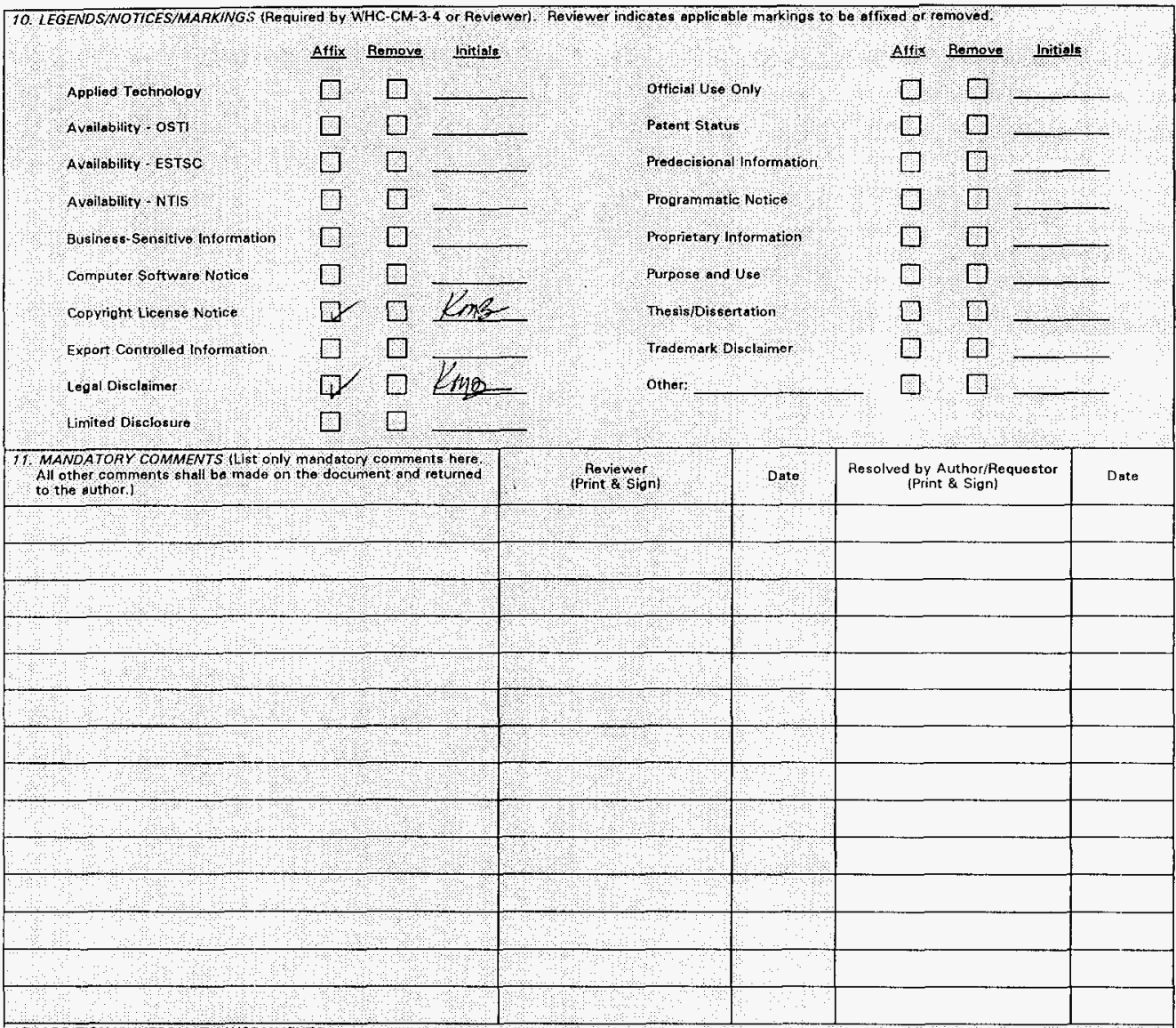


Mobile X-Ray Imaging systems for the Tank waste Characterization project at the Hanford site

\author{
J. R. Weber, J. K. Keve and R. M. Kowitz \\ Westinghouse Hanford Company \\ Richland, Washington \\ Telephone (509) 376-5402 Fax (509) 376-4549

V. J. Alreja
V. J. Technologies
Bohemia, New York
Telephone (516) $589-8800$ Fax (516) $589-8992$

Stored waste tank sampling of radioactive high-level nuclear waste is required for continued operations, waste characterization, and site safety. The Hanford site tank farms consist of 28 doubleshell and 1.49 single-shell underground storage tanks. The "full" capacity of each of these tanks is approximately 1 million gallons. The waste stored in these tanks was generated as a result of defense materials production over the course of 4 decades. The single shell tanks are out-of-service and no longer receive liquid waste. Core samples of salt cake, liquid and sludge are remotely obtained using truck-mounted core drill platforms. Samples are recovered from the tanks through a 2.25-inch diameter drill "pipe" in segments contained in specially designed stainless steel samplers approximately 1.5 -inch in outside diameter and 26-inches long. The sampled material in a given segment can include crystalline salt-cake, liquid, sludge and entrained gas. Drilling parameters will necessarily vary with different waste types, e.g., crystalline salt-cake versus sludge. At times, the core sample recovery has been marginal and inadequate for laboratory analysis needs. This necessitated a system to provide the drill-truck operators with "real-time" feedback about the physical condition of the sampled "formation" and the percent recovery, prior to receiving visual characterization information and nuclear assay measurement:s from the Hanford site 222-S Analytical laboratories, a process often requiring two week turn-around of data. This realtime information allows the drill-truck engineers to immediately vary the drilling parameters to maintain sample recovery.

In February 1995, the Westinghouse Hanford Company conducted initial engineering and proof-of principal radiographic testing to verify the feasibility of a proposed real-time $x$-ray imaging system. These tests were conducted using iridium 192 radiography sources to determine the effects of high levels of radiation on displayed/observed image quality. The tests concluded that samplers with dose rates in excess of $4500 \mathrm{R} / \mathrm{hr}$ could be imaged with only a slight loss of image quality and samples less than 1000 
R/hr had virtually no effect on the real-time image (See figures 1 and 2). The Mobile Core Sample X-ray Imaging (XRI) Systems, are a vendor-designed assembly, which have the component parts uniquely configured to produce a real-time radiographic system suitable for safely examining high level, radioactive waste tank core segments sometimes containing high levels of flammable gasses. These systems (4 in total) have been operated in a low quality, rather severe industrial environment, with temperatures ranging from minus 10 to 108 degrees Fahrenheit for a period of over 18 months. The individual units are periodically removed from the field for routine maintenance and inspection (approximately 6 months). The system was designed to allow for the highly contaminated components of the $\mathrm{X}$-ray imaging system to be easily removed in the field and disposed of, prior to routine servicing.

The primary purpose for the Mobile Core Sample $X-R a y$ Examination. Systems is to examine the core segments for physical contents of the sampler after its removal from the high-level waste tank and prior to placement in a heavily shielded on-site transfer cask. To comply with environmental regulations, the sample segments enter and leave the $\mathrm{X}$-ray system through a vapor sealed adaptor coupled to the drill platform. Sample manipulation (raising/lowering) within a sealed PVC contamination control sleeve is controlled by the drill platform operators. The radiographic region of interest extends from the bottom (closure valve) of the sampler upward 19 to 26 inches. The examination system uses highly stabilized $160 \mathrm{kV}$ X-rays to determine sample contents and approximate the fill volume within 1 to 2 percent prior to shipping the sample to analytical laboratory facilities. When requested, high resolution, hard-copy $X$-ray image prints of the sample are immediately available in the field to evaluate drilling performance and estimate percent sample recovery. The entire examination is recorded on broadcast quality video tape for further review and analysis. The time required for this detailed, in-field, inspection is currently about 10 minutes.

The system is equipped with a minimum thickness of 1 -inch of fully enclcsed, integral lead shielding. All accesses to the main $\mathrm{X}$-ray cabinet (the two lower cabinet access panels, the main $\mathrm{X}-\mathrm{ray}$ cabinet cover-lid and cam-lock adaptor coupling) have a series of safety interlock switches, all of which must be closed before $X-$ rays can be generated. These interlocks are monitored by a microprocessor-based control system which will prevent activation of the "switching-on" circuit of the $\mathrm{x}$-ray controller if any interlock j.s not satisfied or closed. The X-ray control system also separately monitors the warning lights circuits and will not allow $\mathrm{X}$-ray production in the event of a light failure. The entire system has been engineered to be completely "fail-safe' in accordance with federal and state laws and to provide the highest degree of safety.

The mobile imaging system features real-time radiography components that include; a medical quality image intensifier, a 160 $\mathrm{kV}$, constant potential industrial X-ray system, an image processor 
and time/date generator, a video recorder, a high resolution hard copy printer, a live video display, a processed video display, and a darkened operator viewing area. System electrical power is provided by a separate generator. The shielded cabinet protects operating personnel from radiation emitted from the $x-r a y$ examination equipment and the core sample in the main $\mathrm{X}-\mathrm{ray}$ enclosure cabinet. The image viewing monitors and the controls for the system are protected from weather by a hinged cover. For maneuverability and ease of deployment within the tank farms, the system is mounted on, and easily detachable from a small, 7000 pound capacity, utility trailer. The wHC has acquired a total of four XRI systems, to complement four core-sample drill trucks. The XRI systems have been operated at temperatures ranging from minus 10 degrees to 108 degrees Fahrenheit for periods as long as 7 months without requiring maintenance/service.

At this time more than 150 core sample segments, some with dose rates of 12 to $15 \mathrm{R} / \mathrm{hr}$ have been examined. Analytical laboratory results, photographs and observed data support the image information obtained with the radiographs. Because of the prototype equipments value for gathering data and the initial success of mobile system XRI-001, three more mobile X-ray imaging systems wexe added to meet the needs of the Hanford site waste Characterization Project. The $\mathrm{X}$-ray imaging systems have been operated in the harsh, field environment at about a 98 percent availability rate since the second week of June 1995, excluding scheduled shutdown for servicing of the 160,000 volt $x$-ray cable connections. The time line for the engineering development and deployment of this system is shown in Figure 4.

In recent developments involving the mobile core sample $\mathrm{X}$-ray systems, V. J Technologies provided a 9 inch, very high resolution linear diode array, imaging software, a display monitor, a continuous thermal printer and an optical disc image storage system which could be installed in the mobile $\mathrm{x}$-ray cabinet systems along with existing components. The linear diode array was positioned immediately in front of the XRI system image intensifier for test and evaluation purposes.

The testing has concluded that it is possible to obtain a full-length, 12-bit depth, digital $x$-ray image of a core sample segment, while simultaneously obtaining a real time, high resolution image of the specimen. It was demonstrated that while operating in a proposed "dual imaging" mode, only a semi-circular, real-time, live image would be available for the system operator. In actual field use, the array would be remotely removed/or "tipped-out-of" the displayed image viewing field when particular features that require a high-resolution image are suspected. The resolution, sensitivity and dynamic range of the proposed digital imaging system are shown in Figure 3.

By adopting this proposed upgrade, a "full-length, full size" image of the core segment could be immediately printed, in the field, for operational and engineering evaluation, percent recovery 
data recording and image archival purposes. Currently the realtime $\mathrm{X}$-ray inspection of the sample segments requires approximately 10 minutes in the field. A proposed up-grade to the mobile XRI systems, would combine digital radiography with the current realtime inspection equipment and would shorten the field examination time to approximately four to five minutes.

The capability of optically stored digital data and immediate availability of random access to image files would broaden the use and usefulness of the information obtained and contained within the radiographs of the core sample segments. Further, by using digital, optical media every subsequent copy of the image data is identical and equal in quality to the original. 
WHC-SA-3122-FP

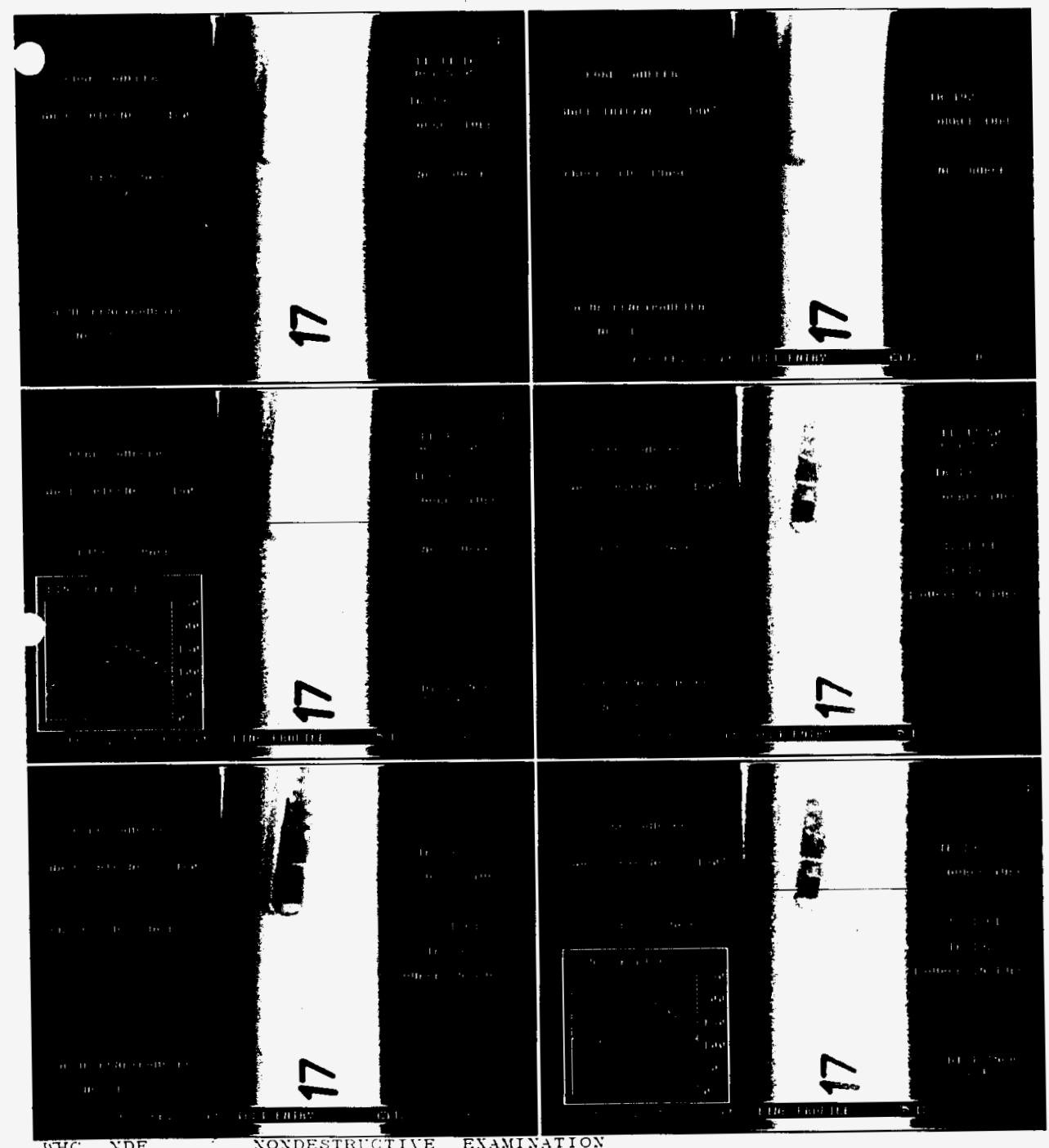

FIGURE 1 
WHC-SA-3122-FP

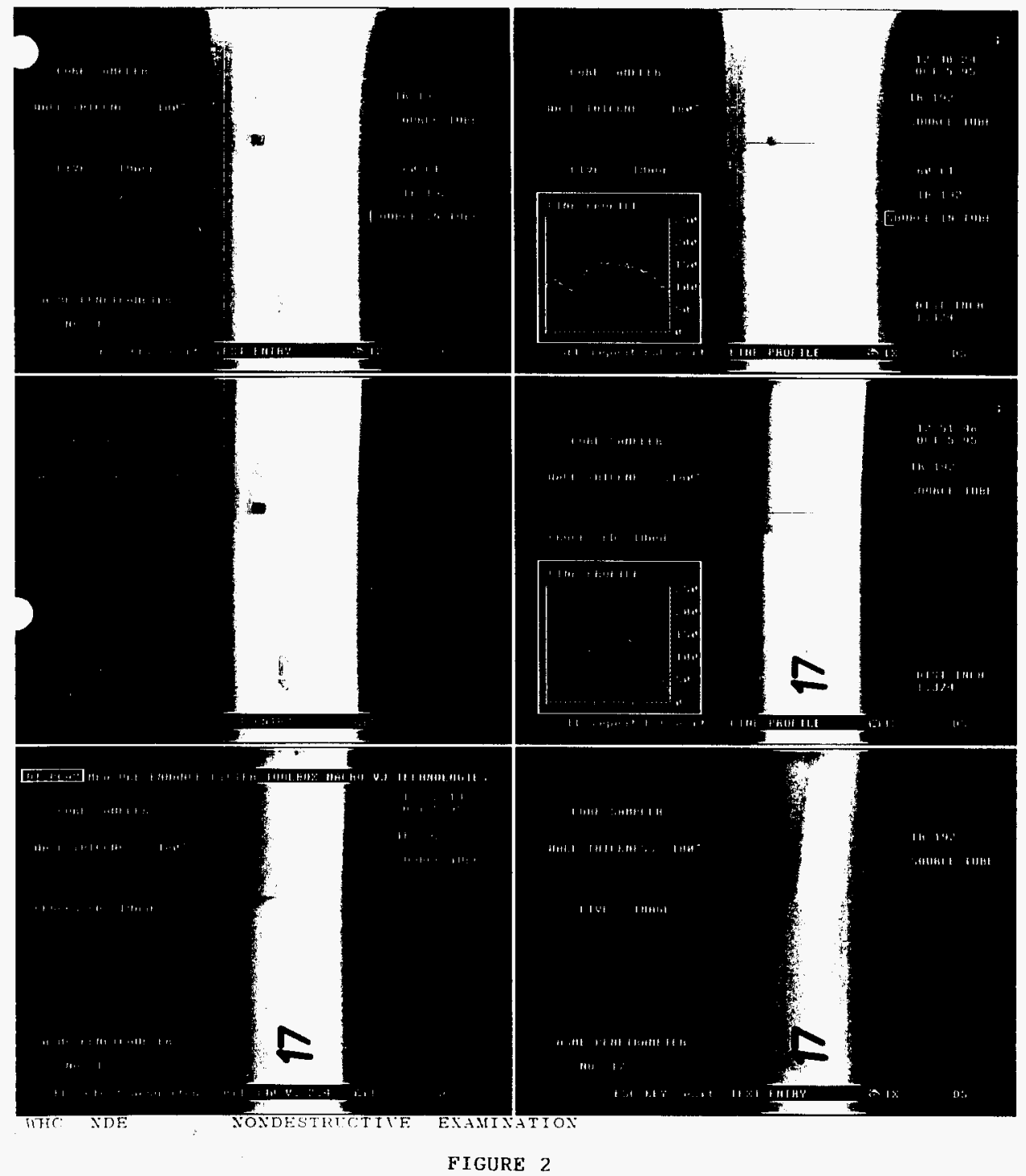


Linear Diode Array Image, $120 \mathrm{kV}$, through 0.063 inch Stainless Steel Plate
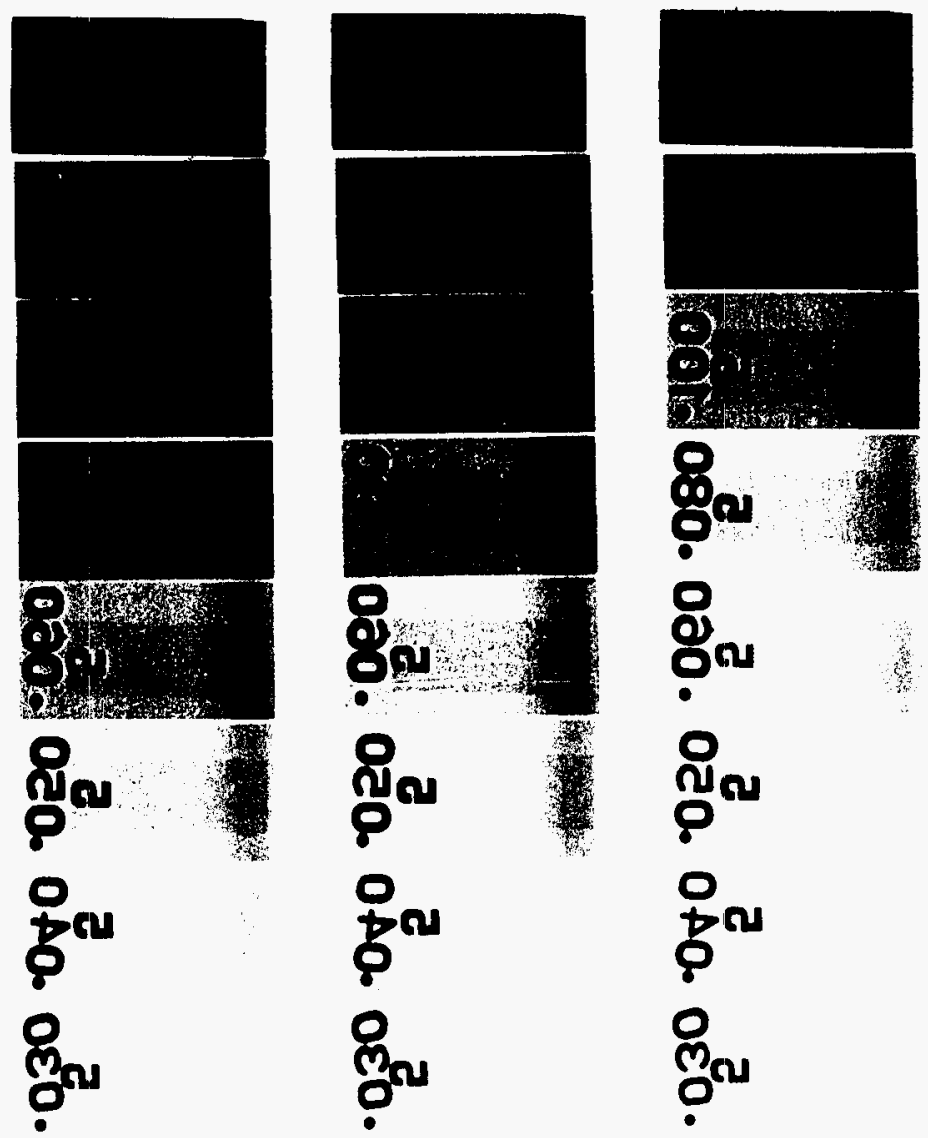

LUT; $0160 \mathrm{~L}, 3000 \mathrm{H}$

$$
\text { LUT; } 0160 \mathrm{~L}, 2500 \mathrm{H}
$$

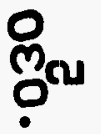

LUT; 0080L, 3000H

Figure 3 
Mobile Core Sample X-Ray Imaging Systems

\begin{tabular}{|c|c|c|c|}
\hline$\bullet$ & February 1995 & - & Concept Proposed \\
\hline$\bullet$ & February 13， 1995 & - & Authorized \\
\hline$\bullet$ & February 22, 1995 & - & $\begin{array}{l}\text { NDE Proof-of-Principal Testing } \\
\text { Completed }\end{array}$ \\
\hline$\bullet$ & March 3, 1995 & - & $\begin{array}{l}\text { Functional and Technical } \\
\text { Requirements Completed and } \\
\text { Reviewed }\end{array}$ \\
\hline$\bullet$ & March 10, 1995 & - & Request for Proposal Issued \\
\hline$\bullet$ & April 10, 1995 & - & Contract Awarded \\
\hline$\bullet$ & May 30,1995 & - & $\begin{array}{l}\text { System XRI-001 Received } \\
\text { Hanford }\end{array}$ \\
\hline$\bullet$ & June 14,1995 & - & Operational Tests Completed \\
\hline • & June 19,1995 & - & $\begin{array}{l}\text { System Accepted and Available } \\
\text { for In-Field Service and Use }\end{array}$ \\
\hline$\bullet$ & July 11, 1995 & - & System First Used at Tank BY-110 \\
\hline$\bullet$ & August 1995 & - & $\begin{array}{l}\text { Request for Proposal, Three } \\
\text { Additional Up-graded Units }\end{array}$ \\
\hline$\bullet$ & September 1995 & - & Contract Awarded \\
\hline • & November 23,1995 & - & $\begin{array}{l}\text { Receipt of } \\
\text { Unit }\end{array}$ \\
\hline & January 10, 1996 & - & All Four System In-Field for Use \\
\hline
\end{tabular}

FIGURE 4 
WHC-SA-3122-FP

\section{DISTRIBUTION}

Number of Copies

1

U. S. Department of Energy

Richland operations office

P. R. Hernandez \$7-54

10

Westinghouse Hanford Company

D. W. Hamilton

S7-12

J. K. Keve

R. M. Kowitz

L6-36

J. C. Krogness

L6-36

R. E. Raymond

L6-36

J. R. Weber (3)

S7 -12

Central Files

S7-12

DPC

A3-88

A3-94 